\title{
Biochemical Properties of Hemagglutinins in the Red Alga Serraticardia maxima
}

\author{
Kazuo ShIOMI*, Hideaki YaMANAKA*, and Takeaki KıKUCHI* \\ (Received July 2, 1980)
}

\begin{abstract}
The red alga Serraticardia maxima was found to possess hemagglutinins against various kinds of animal erythrocytes, and some biochemical properties of the hemagglutinins were examined. In an adsorption test with horse erythrocytes, the activity disappeared against horse, rabbit and guinea pig erythrocytes. The hemagglutinins were unstable to dialysis. The activity was completely lost by heating at $60^{\circ} \mathrm{C}$ and $70^{\circ} \mathrm{C}$ but not at $80^{\circ} \mathrm{C}$ and $90^{\circ} \mathrm{C}$; the results indicate the presence of an unknown factor which inactivates the hemagglutinins at $60^{\circ} \mathrm{C}-70^{\circ} \mathrm{C}$ but not at $80^{\circ} \mathrm{C}-90^{\circ} \mathrm{C}$. The hemagglutinins were stable over a wide range of $\mathrm{pH}$ values between 4 and 10. Their activity was not affected by the divalent metal cations or the simple sugars tested. A single peak with hemagglutinating activity was observed in gel filtration on Sephacryl S-200. The molecular weight of the hemagglutinins was estimated to be about 25,000 from the elution position. These results were different in several points from those previously reported with the hemagglutinins of two red algae, Agardhiella tenera and Cystoclonium purpureum.
\end{abstract}

Hemagglutinins are now becoming useful tools in immunology, cancer research, and other areas of research activities because of their unique biological and physicochemical properties. Previous studies revealed that hemagglutinins are proteins or glycoproteins and have specificities for carbohydrate structures ${ }^{1-5)}$. However, the studies have been concentrated on higher plants and invertebrates and little has been studied on marine algae. Boyd et $a l^{6}{ }^{6}$ and BLUNDEN et al. ${ }^{7)}$, who screened for hemagglutinins against human erythrocytes in tropical marine algae and British marine algae, respectively, reported that some species gave positive results but the activity was weak. On the other hand, because some of the important hemagglutinins such as concanavalin $\mathrm{A}$ are negative or weakly active against human erythrocytes, SHIomI et $a l^{8)}$ surveyed for hemagglutinins in marine algae on the northeast coast of the United States using not only human erythrocytes but also several animal erythrocytes. Their results indicated that a number of algae are active against animal erythrocytes, but negative or only weakly active against human erythrocytes. Moreover, they succeeded in isolating the hemagglutinins from two species of red algae, Agardhiella tenera ${ }^{8)}$ and Cystoclonium purpureum $^{\theta}$. Thus the use of animal erythrocytes was considered to be very effective to study marine algal hemagglutinins.
Therefore, we used only animal erythrocytes and didn't use human erythrocytes in screening for hemagglutinins in Japanese marine algae. The results of the screening revealed that hemagglutinins were contained in many species (unpublished data).

This paper deals with some of the biochemical properties of hemagglutinins in the red alga Serraticardia maxima which is one of the active species confirmed by our screening.

\section{Materials and Methods}

\section{Seaweed}

Samples of the red alga S. maxima were collected at Kominato, Chiba Prefecture, in December, 1979. Immediately after shipping to our laboratory, they were lyophilized and ground to powder. The powdered sample was stored at $-20^{\circ} \mathrm{C}$ until use.

\section{Preparation of Sample Solution}

The powdered sample was homogenized with 10 -folds its volume of buffered saline $(0.15 \mathrm{M} \mathrm{NaCl}$ in $0.01 \mathrm{M}$ phosphate buffer, $\mathrm{pH} 7.0$ ) and centrifuged. The resultant supernatant was used for the determination of hemagglutinating activity. For the examination of other biochemical properties of hemagglutinins, the powdered sample was extracted three times with 4-folds its volume of

* Department of Food Science and Technology, Tokyo University of Fisheries, Konan-4, Minato-ku, Tokyo 108 （塩見一雄・山中英明・菊池武昭：東京水産大学食品生産化学科）. 
buffered saline. To the extracts was added slowly solid $\left(\mathrm{NH}_{4}\right)_{2} \mathrm{SO}_{4}$ at $4^{\circ} \mathrm{C}$ to give a final concentration of $40 \%$ saturation. After removing the precipitate by centrifugation, more solid $\left(\mathrm{NH}_{4}\right)_{2} \mathrm{SO}_{4}$ was added slowly to the supernatant to give a final concentration of $70 \%$ saturation. The solution was kept at $4^{\circ} \mathrm{C}$ overnight and then centrifuged. The resultant precipitate, in which activity was quantitatively found, was dissolved in the buffered saline and used.

\section{Erythrocytes}

Horse, cow, sheep, guinea pig and chicken blood were obtained from Nippon Bio-Supp. Center, and rabbit and mouse blood from the animals kept in our laboratory. A $2 \%$ erythrocyte suspension in buffered saline was prepared from each type of blood after washing three times with buffered saline. To prepare enzyme-treated erythrocytes, $10 \mathrm{mg}$ of trypsin $(223 \mathrm{u} / \mathrm{mg}$, Worthington) or protease (type IV, Sigma) was added to $10 \mathrm{ml}$ of the above $2 \%$ erythrocyte suspension. After incubation of the mixture with shaking at $37^{\circ} \mathrm{C}$ for $30 \mathrm{~min}$, the enzyme-treated erythrocytes were packed by centrifugation and then washed three times with buffered saline. Finally the enzyme-treated erythrocytes were suspended in the original volume of buffered saline.

\section{Assay Method of Hemagglutinating Activity}

Hemagglutinating activity was determined by the method of SHIomi et $a l^{8)}$ in which samples were prepared by serial 2-fold dilution. The results were expressed in terms of titer value, which was defined as reciprocal of the highest dilution of sample that gave positive hemagglutination.

\section{Adsorption of Hemagglutinins with Horse Ery - throcytes}

Horse erythrocytes collected from $1 \mathrm{~m} l$ of blood were washed three times with buffered saline. To the washed horse erythrocytes was added $1 \mathrm{ml}$ of sample solution and the mixture was allowed to stand at $4^{\circ} \mathrm{C}$ for $2 \mathrm{~h}$. After removing the completely agglutinated erythrocytes by centrifugation, the supernatant was tested for activity against horse, rabbit and guinea pig erythrocytes.

Effect of Dialysis, Heat, $p H$ and Metal Ions on Hemagglutinating Activity

A $2 \%$ horse erythrocyte suspension was used in determining the effect of dialysis, heat, $\mathrm{pH}$ and metal ions on hemagglutinating activity. Two $\mathrm{ml}$ of sample solution was dialyzed against $200 \mathrm{~m} /$ of distilled water at $4^{\circ} \mathrm{C}$ for $24 \mathrm{~h}$. After dialysis, both inner and outer solutions were lyophilized and dissolved in $2 \mathrm{~m} l$ of buffered saline and distilled water, respectively. The mixture of equal volume of both solutions was also prepared. Each solution was tested for activity. For the heat stability, $0.5 \mathrm{ml}$ of each solution was heated at 40,50,60, 70,80 and $90^{\circ} \mathrm{C}$ for $30 \mathrm{~min}$. After heating, each solution was cooled and any precipitate formed was removed by centrifugation. The supernatant was tested for activity. To estimate the $\mathrm{pH}$ effect on activity, $1 \mathrm{ml}$ of each solution (pH 6.4) was adjusted to $\mathrm{pH}$ values $2,3,4,5,8,9,10,11$ and 12 with $2 \mathrm{~N} \mathrm{HCl}$ or $2 \mathrm{~N} \mathrm{NaOH}$. The activity was determined after keeping each solution at $4^{\circ} \mathrm{C}$ for $16 \mathrm{~h}$. To evaluate the effect of divalent metal ions, $\mathrm{CaCl}_{2}, \mathrm{MgCl}_{2}$ or $\mathrm{MnCl}_{2}$ was added to $1 \mathrm{ml}$ of sample solution to give a concentration of $0.01 \mathrm{M}$. Each mixture was allowed to stand at room temperature for $2 \mathrm{~h}$ and then examined for activity.

\section{Inhibition Assay by Simple Sugars}

The following simple sugars were used: Dglucose, D-glucosamine, N-acetyl-D-glucosamine, D-galactose, N-acetyl-D-galactosamine, D-mannose, L-fucose, D-arabinose, L-arabinose, D-ribose, Dsorbitol, D-maltose, $i$-inositol, D-lactose, and cellobiose. The inhibition effect of simple sugars on the activity was checked as follows. To each $25 \mu l$ of the sample solution was added each $25 \mu l$ of the buffered saline solution containing various amounts of simple sugars. After incubation of the mixture at room temperature for $2 \mathrm{~h}, 50 \mu \mathrm{l}$ of a $2 \%$ horse erythrocyte suspension was added to each mixture. The results were evaluated after $2 \mathrm{~h}$.

\section{Gel Filtration}

Gel filtration was performed on a Sephacryl S-200 column $(2.5 \times 100 \mathrm{~cm})$ with buffered saline. Fractions of $6 \mathrm{~m} l$ were collected at a flow rate of $30 \mathrm{ml} / \mathrm{h}$. Absorbance at $280 \mathrm{~nm}$ and hemagglutinating activity against horse erythrocytes were determined with each fraction. To estimate the approximate molecular weight of hemagglutinins, three reference proteins, bovine serum albumin (MW 67,000), egg albumin (MW 45,000) and cytochrome c (MW 12,500), were also passed through the same column.

\section{Results and Discussion}

\section{Activity of S. Maxima Hemagglutinins}

There have been no descriptions on the $S$. maxima hemagglutinins in the previous screening 
Table 1. Hemagglutinin titers of the crude extract from $S$. maxima

\begin{tabular}{lccc}
\hline \multirow{2}{*}{ Animals } & \multicolumn{3}{c}{ Erythrocytes } \\
\cline { 2 - 4 } & $\begin{array}{c}\text { Non- } \\
\text { treated }\end{array}$ & $\begin{array}{c}\text { Trypsin- } \\
\text { treated }\end{array}$ & $\begin{array}{c}\text { Protease- } \\
\text { treated }\end{array}$ \\
\hline Horse & 16 & 4 & 8 \\
Cow & $<2$ & 64 & 4 \\
Sheep & 4 & 16 & 8 \\
Rabbit & 4 & 8 & 8 \\
Guinea pig & 8 & 2 & 8 \\
Mouse & 2 & 4 & 2 \\
Chicken & 2 & 16 & 8 \\
\hline
\end{tabular}

$\operatorname{data}^{8,7)}$. The present study first proved that the red alga $S$. maxima contains hemagglutinins that are active against various kinds of animal erythrocytes. As shown in Table 1, the crude extract agglutinates all the animal erythrocytes tested, regardless whether they are treated with enzymes or not; one exception was with non-treated cow erythrocytes. Among the non-treated erythrocytes tested, horse erythrocytes were most agglutinated (titer 16). In this point there was a distinct difference between the $S$. maxima hemagglutinins, and the $A$. tener $a$ and $C$. purpureum hemagglutinins. The latters had been studied previously on the activity against several kinds of non-treated animal erythrocytes; they were highly active against guinea pig and rabbit erythrocytes but only weakly active against horse erythrocytes ${ }^{8,9}$. It should be also pointed out that the susceptibility of agglutination of erythrocytes was changed when they were treated with proteolytic enzymes. For example, by the enzyme treatment the activity was decreased against horse erythrocytes, but increased against chicken erythrocytes. Especially, it was interesting that cow erythrocytes became most active (titer 64 ) among all the erythrocytes tested after the trypsin treatment though almost no response was observed originally without the treatment. This kind of change in the susceptibility of agglutination of erythrocytes by an enzyme treatment is also known for many other hemagglutinins. ${ }^{1-5)}$ The above change occurred with the S.maxima hemagglutinins may be explained by the following hypothesis established with other hemagglutinins. ${ }^{10)}$ In one case the receptors for hemagglutinins in the erythrocyte membrane become mobile on the membrane surface after the enzyme treatment, and easier agglutination of erythrocytes results. In another case the receptors are removed from the membrane or inactivated by uncertain reasons and reduction in agglutination of erythrocytes occurs.
Adsorption of Hemagglutinins with Horse Erythrocytes

When the $S$. maxima hemagglutinins were incubated with horse erythrocytes, the activity against horse erythrocytes reduced drastically (Table 2). This reduction seems to be due to the adsorption of hemagglutinins with horse erythrocytes, since hemagglutinins are generally recognized to reveal their activity by binding to the specific carbohydrate receptors in the cell membrane. A similar reduction in activity was also observed with rabbit and guinea pig erythrocytes (Table 2). Because no more hemagglutinins were available for rabbit and guinea pig erythrocytes after the adsorption with horse erythrocytes, $S$. maxima may contain only one hemagglutinin component. Another possibility suggested is that there are two or more components, but each of the components bears a similar cell specificity and is adsorbed quantitatively by horse erythrocytes.

Table 2. Hemagglutinin titers before and after adsorption with horse erythrocytes

\begin{tabular}{lcc}
\hline Erythrocytes of: & $\begin{array}{c}\text { Before } \\
\text { adsorption }\end{array}$ & $\begin{array}{c}\text { After } \\
\text { adsorption }\end{array}$ \\
\hline Horse & 64 & 2 \\
Rabbit & 16 & $<2$ \\
Guinea pig & 32 & $<2$ \\
\hline
\end{tabular}

\section{Factors Affecting Hemagglutinating Activity}

After dialysis, no activity was found in inner and outer solutions and even in the mixture of both solutions. Certain moieties required for the activity might be in the molecules and cleavaged off during dialysis.

Table 3. Heat stability of S. maxima hemagglutinins

\begin{tabular}{cc}
\hline Treatment & $\begin{array}{c}\text { Hemagglutinin titers against } \\
\text { horse erythrocytes }\end{array}$ \\
\hline $40^{\circ} \mathrm{C}, 30 \mathrm{~min}$ & 32 \\
$50^{\circ} \mathrm{C}, 30 \mathrm{~min}$ & 8 \\
$60^{\circ} \mathrm{C}, 30 \mathrm{~min}$ & $<2$ \\
$70^{\circ} \mathrm{C}, 30 \mathrm{~min}$ & $<2$ \\
$80^{\circ} \mathrm{C}, 30 \mathrm{~min}$ & 4 \\
$90^{\circ} \mathrm{C}, 30 \mathrm{~min}$ & 8 \\
Non-treated & 64 \\
\hline
\end{tabular}

The heat stability was quite strange as shown in Table 2. The activity was reduced by heating at 40 and $50^{\circ} \mathrm{C}$, and almost completely lost at 60 and $70^{\circ} \mathrm{C}$. However, when heated at 80 and $90^{\circ} \mathrm{C}$, the activity came back though it was not strong. The similar phenomenon is known for 


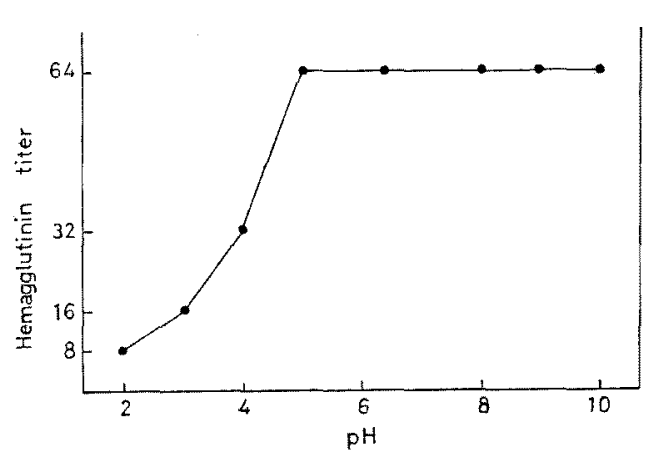

Fig. 1. Effect of pH on the activity of S. maxima hemagglutinins against horse erythrocytes.

the thermostable hemolysin in the culture filtrate of a microorganism Vibrio parahaemolyticus. In the case of $V$. parahaemolyticus, an inactivating factor, which interacts with the hemolysin at around $50^{\circ} \mathrm{C}$, was demonstrated. $\left.{ }^{11}\right)$ The $S$. maxima hemagglutinins also seem to be inactivated by an unknown factor which acts at $60-70^{\circ} \mathrm{C}$ but not at $80-90^{\circ} \mathrm{C}$. For more detailed discussion on the heat stability, purification of the hemagglutinins is necessary.

Fig. 1 shows the pH effect on the hemagglutinating activity. The results at $\mathrm{pH} 11$ and 12 are not illustrated because they were obscure due to hemolysis. Like the $A$. tenera and $C$. purpureum hemagglutinins, ${ }^{8,8)}$ the $S$. maxima hemagglutinins were fairly stable over a wide range of $\mathrm{pH}$ values between 4 and 10 . Even at $\mathrm{pH} \mathrm{2,} \mathrm{a} \mathrm{part} \mathrm{of} \mathrm{activity} \mathrm{still}$ remained, but the reduction of activity was ir- reversible even when the $\mathrm{pH}$ was returned to neutral.

It is well known that divalent cations are essential for the activity of some higher plant and invertebrate hemagglutinins. Three divalent metal cations, $\mathrm{Mn}^{2+}, \mathrm{Ca}^{2+}$, and $\mathrm{Mg}^{2+}$, however, exhibited neither inhibition nor accerelation on the activity of $S$. maxima hemagglutinins. The same results were reported for the $A$. tenera and $C$. purpureum hemagglutinins ${ }^{8,8)}$.

The simple sugars tested showed no inhibition of activity at a concentration of $2.5 \mathrm{mg} / \mathrm{ml}$. The results can be interpreted in the same way as explained in the case of the $A$. tenera and $C$. purpureum hemagglutinins $^{8, \theta)}$ with which the inhibition by simple sugars did not occur. That is, the carbohydrate binding site of $S$. maxima hemagglutinins has no affinity to the simple sugars tested, but would show specific affinities to more complex carbohydrates.

\section{Gel Filtration}

As shown in Fig. 2, the $S$. maxima hemagglutinins were eluted from a Sephacryl S-200 column as a single peak. The elution behavior may support the possibility stated previously that S.maxima contains only one hemagglutinin component. Even though several components are present in the alga, it is evident that the molecular weight of each hemagglutinin component is almost the same. From the elution position between egg albumin and cytochrome $c$, the molecular weight was calculated to be around 25,000 . This value was fairly large compared with those $(12,000-13,000)$

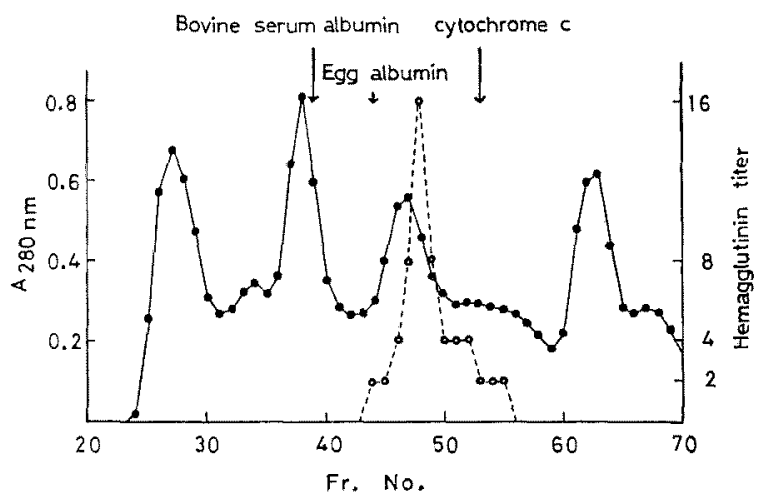

Fig. 2. Gel filtration of the S. maxima hemagglutinins on Sephacryl $S-200$.

Column size, $2.5 \times 100 \mathrm{~cm}$; solvent, $0.15 \mathrm{M} \mathrm{NaCl}$ in $0.01 \mathrm{M}$ phosphate buffer (pH 7.0). Fractions of $6 \mathrm{~m} /$ were collected at a flow rate of $30 \mathrm{~m} / / \mathrm{h}$. - absorbance at $280 \mathrm{~nm} ; 0 \cdots-$, hemagglutinin titer against horse erythrocytes. The arrows represent the elution position of reference proteins. 
reported for the $A$. tenera and $C$. purpureum hemagglutinins. ${ }^{8, \theta)}$

\section{Acknowledgement}

The authors wish to thank Professor M. KatadA and Mr. and Mrs. S. AraI, Tokyo University of Fisheries, for collecting and identifying samples, and Dr. M. ChibA, Vineland Research Station, Agriculture Canada, for revising this manuscript.

\section{References}

1) T. Osawa: Tanpakushitsu Kakusan Koso, 16, 335-349 (1971).

2) N. SHARON and H. Lis: Science, 177, 949-959 (1972).
3) H. Lis and N. Sharon: Annu. Rev. Biochem., 42, 541-573 (1973).

4) K. Shimada and T. Mizuno: Kagaku no Ryoiki, 29, 282-290 (1975).

5) E. R. Gold and P. Balding: Receptor-Specific Proteins, Plant and Animal Lectins, Excerpta Medica, Amsterdam, 1975.

6) W. C. Boyd, L. R. Almodovar, and L. G. Boyd: Transfusion (Philadelphia), 6, 82-83 (1966).

7) G. Blunden, D. J. Rogers, and W. Faruham; Lloydia, 38, 162-168 (1975).

8) K. SHIomi, H. KAMIYA, and Y. ShimizU: Biochim. Biophys. Acta, 576, 118-127 (1979).

9) H. KamiYa, K. ShIomi, and Y. Shimizu: Lloydia, 43, 136-139 (1980).

10) G. L. Nicolson: Biochim. Biophys. Acta, 458, 1-72 (1976).

11) Y. Takeda, Y. Hori, S. TAGa, J. SakuRal, and T. MiWatani: Infect. Immun., 12, 449-454 (1975). 